\title{
Nutritional Value of the Egyptian Freshwater Bivalve Spathopsis rubens arcuata Under the Effect of Depuration
}

\author{
Gihan M. Elkhodary ${ }^{1 *}$, Nahla E. Omran², Amal A. Hassan¹, Salwa A. El-Saidy ${ }^{1}$ and Mohamed H. Mona ${ }^{2}$ \\ ${ }^{1}$ Faculty of Science, Department of Zoology, Damanhour University, Egypt \\ ${ }^{2}$ Faculty of Science, Department of Zoology, Tanta University, Egypt
}

\begin{abstract}
On the view of finding a new source of protein, Spathopsis rubens arcuata is one of fresh water bivalves inhabiting Nile River, Egypt. The quality of this clam as a human food was investigated. The herein results showed that $S$. rubens arcuata is a good source of protein, carbohydrate and with a negligible source of fat when compared with edible fishes. Myristic acid was the most abundant saturated fatty acid (SFA) while Myristoleic acid and Linoleic acid were the two most abundant unsaturated fatty acids. The nonessential amino acid Glutamine is the most dominant amino acid followed by Aspartic, Alanine and Leucine. Studying the safety of consuming the investigated clam was based on: 1) Studying the heavy metal content in relation to the environment and after a depuration period, 2) Studying the associated parasites. The results showed that the initial heavy metals $(\mathrm{Cu}, \mathrm{Cd}$ and $\mathrm{Pb})$ concentrations detected in soft tissues of the clam were high and exceeded the legal values. But the 8 days of depuration was an excellent strategy to reduce $\mathrm{Cu}, \mathrm{Cd}$ and $\mathrm{Pb}$ to an acceptable level for human consumption. Seasonal study of the clam associated parasite showed that $S$. rubens arcuata harbors nonpathogenic ciliated protozoa Conchophthirus sp. and an annelid Batracobdelloides tricarinata as commensal organisms and a trematode Aspidogaster conchicola as a parasite. The present work concludes that $S$. rubens arcuata can be a good source of food for human on condition that arises in the market after a period of depuration reached to 8 days.
\end{abstract}

Keywords: Bivalves; Depuration; Fatty acids; Amino acids; Parasites

\section{Introduction}

Mollusks, especially bivalves clams and mussels are an important food source for humans. It is well known that clams are a good source of some important nutrients such as proteins, carbohydrates, steroids, minerals, especially iron, zinc, and copper, and vitamins such as vitamin B-12. Also, these shellfish can be considered as a reliable source of fats especially saturated one and have a high content of the omega-3 fatty acids [1]. The shellfish have cholesterol concentrations of less than 80 milligrams per 100 grams (edible portion) therefore, can be consumed by people trying to limit their dietary cholesterol intake [2]. They provide a high-quality protein with almost all the dietary essential amino acids [3]. They also generally store carbohydrates in large amounts during their growing season and use them over the rest of the year [4]. Although proteins may be an energy reserve in some bivalve species $[5,6]$.

Different toxins might be accumulated in these clams under certain conditions [7] This risk is increased due to eating these clams raw or lightly cooked [8]. To minimize this risk, the source of the shellfish should be investigated, and better quality would be attained by appropriate treatment following the harvest. The best strategy that has been developed for bivalve risk management is the depuration [9]. The depuration helps bivalves to expel and isolate contaminants from their gills and intestinal tract over a period. The most abundant heavy metals such as copper $(\mathrm{Cu})$, lead $(\mathrm{Pb})$ and cadmium $(\mathrm{Cd})$ were found in the Egyptian irrigation system [10].

In Egypt, S. rubens arcuata is among the benthic invertebrates in an irrigation canal that in direct contact with heavy metals both of natural and anthropogenic origin. The quality and economic importance of this species are still unknown. The present work aimed to investigate the effect of the depuration on the nutritional value of $S$. rubens arcuata clams, assessment of the most abundant heavy metals in their tissues and the prevalence of the infection rates of different parasites which could be hosted in the clams tissues.

\section{Materials and Methods}

\section{Samples collection}

Spathopsis ruben arcuata were collected from Al-Mahmoudia irrigation canal at Damanhour, El-Beheira Governorate, Egypt. Dead or damaged specimens were eliminated and a standardized shell size, only shell sizes ranged from 110 to $130 \mathrm{~mm}$ in length and 23 to $41 \mathrm{~mm}$ in width were used.

\section{Depuration experiment}

The depuration experiment was commenced within $4 \mathrm{~h}$ of shellfish collection. Depuration was studied for three and eight days. Ten clams were placed in aquaria contained 10 litters dechlorinated tap water in three replicates under laboratory conditions and with continuous aeration. Water was changed and replaced with new dechlorinated tap water and the aquaria were cleaned every day to avoid refiltration of depurate contaminants.

\section{Heavy metal analysis}

Heavy metal $(\mathrm{Cu}, \mathrm{Cd}$, and $\mathrm{Pb})$ concentrations in soft tissues of $S$. rubens arcuata were analyzed according to Pearson's chemical analysis of foods [11] by using an atomic absorption spectrophotometer Shimadzu model (AA-6650). The results of metal concentrations are expressed as $\mu \mathrm{g} / \mathrm{g}$ of dry weight of soft tissues.

*Corresponding author: Gihan M. Elkhodary, Faculty of Science, Departmen of Zoology, Damanhour University, Egypt, Tel: 01227243516; E-mail: gihankhodary@hotmai.com

Received August 07, 2018; Accepted November 12, 2018; Published November 16, 2018

Citation: Elkhodary GM, Omran NE, Hassan AA, El-Saidy SA, Mona MH (2018) Nutritional Value of the Egyptian Freshwater Bivalve Spathopsis rubens arcuata Under the Effect of Depuration. J Aquac Res Development 9: 551. doi: 10.4172/2155-9546.1000551

Copyright: @ 2018 Elkhodary GM, et al. This is an open-access article distributed under the terms of the Creative Commons Attribution License, which permits unrestricted use, distribution, and reproduction in any medium, provided the original author and source are credited. 


\section{Determination of the chemical composition}

Moisture content was determined according to AOAC in 2000 [12]. Ash was determined according to AOAC in 1986 [13]. Total carbohydrate was determined colorimetrically according to the study of Duboies et al. [14]. Total lipid was analyzed using Soxtherm; Gerhardt, laboratory instrument while total protein was analyzed by Kjeldatherm and Vapadest 50s; Gerhardt, laboratory instrument [15]

\section{Amino acid analysis}

The dried ground sample $(1 \mathrm{~g})$ was put in diethyl ether for 24 hours to remove lipid from it and then dried. 0.3 grams of sample were hydrolyzed with $6 \mathrm{~N} \mathrm{HCl}) 5 \mathrm{~mm}^{3}$ ) in a sealed tube at $110^{\circ} \mathrm{C}$ for 24 hours, then cooled for $10 \mathrm{~min}$. The sample was filtered with the aid of $10 \mathrm{~mm}^{3}$ of distilled water. Thereafter, the sample was put in a water bath for 5 hours till dryness. At the end of this step, the digestion process was finished, and distilled water and HCL were evaporated. The residue of the sample was dissolved in $2 \mathrm{ml}$ of sample dilution (diluting buffer) $(0.2 \mathrm{M}, \mathrm{pH} 2.2)$ to complete the sample dissolving. Amino acid quantities were determined by using an automatic amino acid analyzer [16].

\section{Fatty acid analysis}

In a tube, $50 \mathrm{mg}$ of lipid was weighed, then $5 \mathrm{ml}$ of methanol sulphuric acid ( $1 \mathrm{ml}$ conc. sulphuric acid and $100 \mathrm{ml}$ methanol) and $2 \mathrm{ml}$ of benzene were added. The tube was closed well and placed in a water bath at $90^{\circ} \mathrm{C}$ for an hour and a half. Then, it was cooled, and $8 \mathrm{ml}$ of water and $5 \mathrm{ml}$ of petroleum ether were added. The tube was shaken strongly, and the ethereal layer was separated out in a dry tube. Evaporation was done until dryness occurred. All solution was placed in a tube and put in the oven at $90^{\circ} \mathrm{C}$ for an hour and a half. The resulting methyl esters were analyzed using an Agilent Gas Chromatography system [17].

\section{Examination methods for parasites}

The samples were examined for parasitic infections using shedding method [18]. The thin hemolymph film was prepared for any protozoan parasites according to Abd El-Rahman [19] collected Helminth and annelid samples were identified according to Brooks and Welsch, Hendrix and Overstreet \& Abd El-Rahman [20-22] Scanning electron microscopy (SEM) for helminths and annelids occurs according to Hassan and Saeed [23].

\section{Statistical analysis}

Data on metal contents and biochemical measurements (protein, carbohydrate, lipid, amino, and fatty acids) of S. rubens arcuata were statistically analyzed. One-way analysis of variance (ANOVA) and post-hoc multiple-comparison tests (Tukey) was used. The level of significance was presented at $\mathrm{p}<0.05$. All statistical analyses were performed using the statistical software package SPSS 20.0.

\section{Results}

\section{The heavy metal content of $S$. rubens arcuata}

The results showed that the concentrations of heavy metals $\mathrm{Cu}, \mathrm{Cd}$, and $\mathrm{Pb}(\mu \mathrm{g} / \mathrm{g}$ of dry tissue weight) were gradually decreased in all soft tissues of $S$. rubens arcuataa the depuration period was increased. On the $3^{\text {rd }}$ day of depuration, the levels of heavy metals in the foot, mantle, and adductor muscle tended to decrease in the order $\mathrm{Cd}>\mathrm{Pb}>\mathrm{Cu}$ but tended to decrease in the order $\mathrm{Pb}>\mathrm{Cd}>\mathrm{Cu}$ in the gills. While after 8 days of depuration, the levels of heavy metals in the previous tissues tended to decrease in the order of $\mathrm{Cd}>\mathrm{Pb}>\mathrm{Cu}$. the highest reduction rate of $\mathrm{Cu}$ and $\mathrm{Pb}$ was on the $3^{\text {rd }}$ day of depuration in the gills, while on the foot, the highest reduction rate for the concentration of $\mathrm{Cd}$. On the other hand, at the $8^{\text {th }}$ day of depuration, the reduction rate of $\mathrm{Cu}$ was higher in the gills, but in mantle for the $\mathrm{Pb}$. After 8 days of depuration, $\mathrm{Cu}$ and $\mathrm{Pb}$ showed the lowest percentage in the foot tissues. By day 8 of depuration, all soft tissues were eliminated form $\mathrm{Cd}$ as shown in Table 1.

\section{Biochemical composition of depurated S. rubens arcuata}

The biochemical compositions of the soft parts of $S$. rubens arcuata were assessed after 3- and 8-days post depuration. The moisture percentages were statistically significant increased through the depuration periods $(p=0.000)$. Lipid percentage was not statistically significant changed ( $p>0.05)$ after the depuration for 3 days but significantly decreased after 8 days of depuration $(p<0.05)$. On the other hand, the total protein and carbohydrate contents in S. rubens arcuata after 3 days of depuration significantly decreased $(p=0.003)$, but after 8 days of depuration decreased significantly $(\mathrm{p}=0.000$ and $\mathrm{p}=0.008$, respectively) when compared with the initial content as shown in Table 2 .

\begin{tabular}{|c|c|c|c|c|c|}
\hline \multicolumn{2}{|r|}{ Variables } & Foot & Gill & Mantle & Adductor muscle \\
\hline \multirow{3}{*}{$\mathrm{Cu}$} & $\begin{array}{c}\text { Before } \\
\text { depuration }\end{array}$ & $8.21 \pm 0.34^{c}$ & $11.20 \pm 1.94^{c}$ & $9.47 \pm 0.54^{c}$ & $15.96 \pm 0.75^{b}$ \\
\hline & $\begin{array}{c}3^{\text {rd }} \text { days- post } \\
\text { depuration }\end{array}$ & $7.32 \pm 0.33 b^{b^{*}}$ & $7.52 \pm 0.30 \mathrm{~b}^{\star}$ & $7.37 \underset{\mathrm{b}^{*+}}{ \pm 0.37}$ & $15.96 \pm 0.60^{\mathrm{b}}$ \\
\hline & $\begin{array}{c}8^{\text {th }} \text { days- post } \\
\text { depuration }\end{array}$ & $\begin{array}{c}3.45 \pm 0.12 \\
a^{\star \star *}\end{array}$ & $0.73 \pm \underset{a^{* * *}}{0.02}$ & $2.20 \pm 0.27$ & $1.67 \pm 0.10^{a^{*+*}}$ \\
\hline \multirow{3}{*}{$\mathrm{Cd}$} & $\begin{array}{c}\text { Before } \\
\text { depuration }\end{array}$ & $1.06 \pm 0.14^{c}$ & $0.49 \pm 0.03^{c}$ & $0.27 \pm 0.05^{c}$ & $0.78 \pm 0.08^{c}$ \\
\hline & $\begin{array}{c}3^{\text {rd }} \text { days- post } \\
\text { depuration }\end{array}$ & $0.34 \pm 0.04$ & $0.31 \pm 0.02$ & $0.16 \pm 0.01^{\mathrm{b}^{*}}$ & $0.26 \pm 0.01^{b^{*+* t}}$ \\
\hline & $\begin{array}{c}8^{\text {th }} \text { days- post } \\
\text { depuration }\end{array}$ & N.D ${ }^{a^{*+*}}$ & N.D ${ }^{a^{x+*}}$ & N.D ${ }^{a+* t}$ & $N \cdot D^{a^{*+*}}$ \\
\hline \multirow{3}{*}{$\mathrm{Pb}$} & $\begin{array}{c}\text { Before } \\
\text { depuration }\end{array}$ & $14.35 \pm 1.86^{\mathrm{b}}$ & $\begin{array}{c}10.33^{ \pm} \\
1.12^{\mathrm{c}}\end{array}$ & $4.69 \pm 0.59^{c}$ & $14.96 \pm 0.87^{c}$ \\
\hline & $\begin{array}{c}3^{\text {rd }} \text { days- post } \\
\text { depuration }\end{array}$ & $12.09 \pm 0.06^{b}$ & $6.07 \pm 0.10^{\mathrm{b}^{*+*}}$ & $2.83 \pm 0.30$ & $10.76 \pm 1.89^{\mathrm{b}^{*}}$ \\
\hline & $\begin{array}{c}8^{\text {th }} \text { days- post } \\
\text { depuration }\end{array}$ & $\underset{\mathrm{a}^{*+*+}}{0.85 \pm 0.04}$ & $\underset{a^{* *+*}}{0.21 \pm 0.02}$ & $0.03 \pm \underset{a^{\star \star * *}}{0.003}$ & $0.02^{\mathrm{a}+*+}$ \\
\hline
\end{tabular}

\section{ND: Non-detected}

${ }^{*}$ Significant at $p$-value $\leq 0.05$

** Significant at $p$-value $\leq 0.0$

*** Significant at $p$-value $\leq 0.00$

Values are mean \pm SD.

Different letters $\left.{ }^{(a, b, a n d} c\right)$ in each row for each metal are significant, $p<0.05$ (Oneway ANOVA)

Table 1: The heavy metal concentrations in foot, gill, mantle, and adductor muscle of Spathopsis rubens arcuata, during the first day of collection, third, and eighth day of depuration.

\begin{tabular}{|c|c|c|c|}
\hline \multirow{2}{*}{$\begin{array}{c}\text { Biochemical } \\
\text { composition (\%) }\end{array}$} & $\begin{array}{c}|c| \\
\text { Before } \\
\text { depuration }\end{array}$ & $\begin{array}{c}\text { Day 3 post } \\
\text { depuration }\end{array}$ & $\begin{array}{c}\text { Day 8 post } \\
\text { depuration }\end{array}$ \\
\cline { 2 - 4 } & $20.27 \pm 0.31^{\mathrm{a}^{*+}}$ & $23.78 \pm 0.43^{\mathrm{b}}$ & $54.69 \pm 0.42^{\mathrm{c}+*}$ \\
\hline Moisture & $8.31 \pm 0.18^{\mathrm{c}}$ & $6.29 \pm 0.01^{\mathrm{b}+*}$ & $5.35 \pm 0.07^{\mathrm{a}^{*+*}}$ \\
\hline Ash & $39.17 \pm 0.02^{\mathrm{c}^{* *}}$ & $36.19 \pm 0.41^{\mathrm{b}}$ & $10.35 \pm 0.21^{\text {***t}}$ \\
\hline Proteins & $32.56 \pm 0.15^{\mathrm{c}^{* *}}$ & $30.30 \pm 0.14^{\mathrm{b}}$ & $28.61 \pm 0.28^{\mathrm{a}^{*+*}}$ \\
\hline Carbohydrates & $1.70 \pm 0.14^{\mathrm{b}}$ & $1.41 \pm 0.01^{\mathrm{b}}$ & $1 \pm 0.01^{\mathrm{a}^{*}}$ \\
\hline Lipids & SD: Standard Deviation, F ratio: Frequency, p-value: Probability. \\
\hline
\end{tabular}

Table 2: Biochemical composition in the total soft tissues of Spathopsis rubens arcuata collected from Al-Mahmoudia canal, Zawyet Ghazal, at the first day of collection, third, and eighth days of depuration. Different letters $(a, b, a n d c)$ in each row are significant, $p<0.05$ (one-way ANOVA). 
Citation: Elkhodary GM, Omran NE, Hassan AA, El-Saidy SA, Mona MH (2018) Nutritional Value of the Egyptian Freshwater Bivalve Spathopsis rubens arcuata Under the Effect of Depuration. J Aquac Res Development 9: 551. doi: 10.4172/2155-9546.1000551

Page 3 of 9

\section{Analysis of fatty acid composition after depuration periods}

The contents of fatty acids were detected through Gas Chromatography analysis from soft parts of $S$. rubens arcuata after depuration for 3 days. On the first day of collection and after three days of depuration, 13 different fatty acids in S. rubens arcuata were analyzed including 7 saturated fatty acids (SFA), 4 monounsaturated fatty acids (MUFAs), and 2 polyunsaturated fatty acids (PUFAs). The initial content of the tissue showed that Myristic acid (C14:0) was the most abundant SFA in S. rubens arcuata. The major acid was detected among the MUFAs is Myristoleic acid (C14:1), while Linoleic acid (C18:2c) was in PUFAs. At the first day of collection, there are one MUFA omega 9 (Oleic acid C18:1c), one PUFA omega 3 (Eicosatrienoic acid C20:3w3), and one PUFA omega 6 Linoleic acid C18:2c), while after 3 days of depuration, 20 different fatty acids were detected in S. rubens arcuata tissues including 9 saturated fatty acids (SFA), 5 monounsaturated fatty acids (MUFAs), and 6 polyunsaturated fatty acids (PUFAs). The

\begin{tabular}{|c|c|c|c|}
\hline \multirow{2}{*}{ No } & Fatty acids & \multirow{2}{*}{$\begin{array}{c}\text { Before } \\
\text { depuration }\end{array}$} & \multirow{2}{*}{$\begin{array}{l}\text { Day } 3 \text { post } \\
\text { depuration }\end{array}$} \\
\hline & Saturated fatty acids (SFAs) & & \\
\hline 1 & Caprylic acid & $0.28 \pm 0.01$ & $0.23 \pm 0.04$ \\
\hline 2 & Lauric acid & $3.53 \pm 0.28$ & $1.91 \pm 0.08^{*}$ \\
\hline 3 & Tridecylic acid & $16.02 \pm 0.39$ & $5.11 \pm 0.419^{* * *}$ \\
\hline 4 & Myristic acid & $26.57 \pm 0.41$ & $9.117 \pm 0.453^{\cdots+*}$ \\
\hline 5 & Pentadecylic acid & $11.002 \pm 0.16$ & $5.182 \pm 0.068^{* * *}$ \\
\hline 6 & Palmitic acid & $10.547 \pm 0.65$ & $51.234 \pm 0.045^{* * *+}$ \\
\hline 7 & Margaric acid & N.D. & $2.602 \pm 0.010^{* * *}$ \\
\hline 8 & Stearic acid & $2.318 \pm 0.69$ & $20.793 \pm 0.163^{*+*}$ \\
\hline \multirow[t]{2}{*}{9} & Heneicosylic acid & N.D. & $8.378 \pm 0.104^{* * *}$ \\
\hline & Total saturated fatty acids & $70.281 \pm 2.60$ & $104.573 \pm 0.700^{* *}$ \\
\hline \multicolumn{4}{|c|}{ Monounsaturated fatty acids (MUFAs) } \\
\hline 10 & $\begin{array}{l}\text { Myristoleic acid (Tetradecanoic } \\
\text { acid) }\end{array}$ & $12.36 \pm 0.48$ & $2.300 \pm 0.178^{* * *}$ \\
\hline 11 & 14, Pentadecanooic acid & $9.336 \pm 0.22$ & $3.041 \pm 0.257^{* * *}$ \\
\hline 12 & $\begin{array}{l}\text { Palmitoleic acid (9 Hexadecenoic } \\
\text { acid) }\end{array}$ & $4.706 \pm 0.16$ & $11.266 \pm 0.776^{* *}$ \\
\hline 13 & $\begin{array}{l}\text { Margaroleic acid (Heptadecenoic } \\
\text { acid) }\end{array}$ & N.D. & $2.005 \pm 0.145^{* *}$ \\
\hline 14 & $\begin{array}{c}\text { Oleic acid (Elaidic acid } \mathrm{m} \text { ) Omega } \\
9\end{array}$ & $4.630 \pm 0.23$ & $31.400 \pm 0.502^{*+*}$ \\
\hline & Total & 31.03 & $50.012^{*+*}$ \\
\hline \multicolumn{4}{|c|}{ Polyunsaturated fatty acids (PUFAs) } \\
\hline 15 & $\begin{array}{c}\text { Alpha Linolenic acid (ALA) } \\
\text { Omega } 3\end{array}$ & N.D. & $0.391 \pm 0.006^{*+* t}$ \\
\hline 16 & Linoleic acid (LA) Omega 6 & $4.775 \pm 0.187$ & $31.301 \pm 0.507^{* * *}$ \\
\hline 17 & Arachidonic acid (ARA) Omega 6 & N.D & $15.381 \pm 0.789+*$ \\
\hline 18 & $\begin{array}{c}\text { Eicosapentaenoic acid (EPA) } \\
\text { Omega } 3 \\
\end{array}$ & N.D & $6.610 \pm 0.226^{*+*}$ \\
\hline 19 & $\begin{array}{c}\text { Eicosatrienoic acid (ETA)Omega } \\
3\end{array}$ & $1.879 \pm 0.112$ & $20.683 \pm 0.412$ \\
\hline \multirow[t]{2}{*}{20} & $\begin{array}{c}\text { Docosahexaenoic acid (DHA) } \\
\text { Omega } 3 \\
\end{array}$ & N.D. & $10.715 \pm 0.401^{* * *}$ \\
\hline & Total & 6.654 & $85.081^{\cdots *}$ \\
\hline & Total unsaturated fatty acids & $37.68 \pm 0.156$ & $135.09 \pm 1.045^{*+*}$ \\
\hline & Total fatty acids & $107.96 \pm 2.764$ & $239.66 \pm 0.34^{* * *}$ \\
\hline & Total SFAs/ Total FAs & $65.09 \%$ & $43.632 \%$ \\
\hline & Total UFAs/ Total FAs & $34.90 \%$ & $56.367 \%$ \\
\hline
\end{tabular}

Table 3: Fatty acid analysis of the total soft tissues of Spathopsis rubens arcuata collected from Al-Mahmoudia canal, Zawyet Ghazal during the first day of collection and third day of depuration. Values are concentrations of fatty acids in $\mathrm{mg} / 100 \mathrm{~g}$ of sample. Values are significantly different at $(p<0.05)$
Palmitic acid (C16:0) became the most abundant SFA. While, among the MUFAs, Oleic acid (C18:1c) was the most abundant acid and Linoleic acid (C18:2c) among the PUFAs. Also, in addition to Oleic acid C18:1c (MUFA omega 9), Eicosatrienoic acid C20:3w3 (PUFA omega 3), and Linoleic acid C18:2c (PUFA omega 6) that found in the initial content, there are 3 PUFAs omega 3 (Alpha Linolenic acid C18:3, Eicosapentaenoic acid C20:5, and Docosahexaenoic acid C22:6) and one PUFA omega 6 (Arachidonic acid C20:4) were found after depuration of three days.

Some of the saturated fatty acids such as palmitic acid, stearic acid, margaric acid, and heneicosylic acid and all unsaturated fatty acids, except myristoleic acid and 14, pentadecanoic acid were increased significantly after the $3^{\text {rd }}$ day of depuration $(\mathrm{p}<0.01)$. Furthermore, the overall content of SFAs and UFAs increased significantly after 3 days of depuration ( $\mathrm{p}<0.01$ and $\mathrm{p}=0.000$, respectively). Moreover, the initial content of total saturated fatty acids significantly increased when compared with total unsaturated fatty acids $(p=0.003)$, but after the $3^{\text {rd }}$ day of depuration total unsaturated fatty acids significantly higher

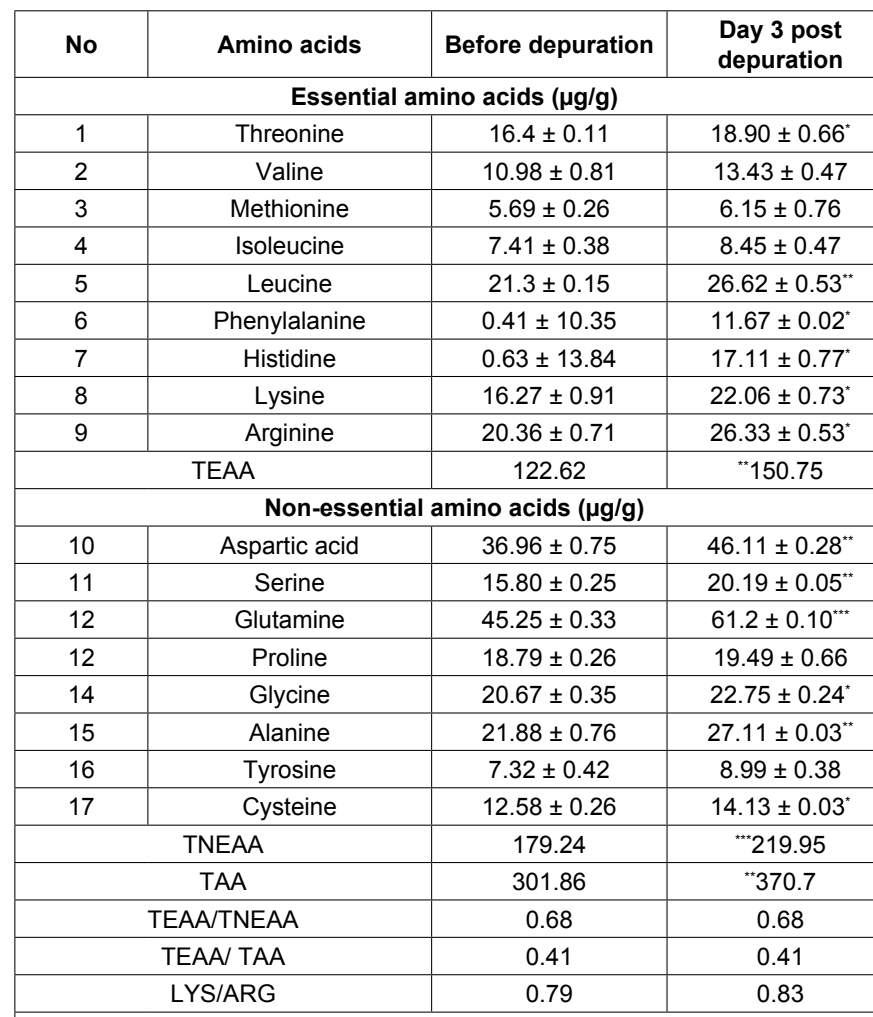

TEAA: Total essential amino acids, TNEAA: Total nonessential amino acids, TAA: Total amino acids, LYS/ARG: Lysine Arginine ratio.

Values are concentrations of amino acids in $\mathrm{ppm}(\mu \mathrm{g} / \mathrm{g})$. Values are significantly different at $(p<0.05)$

Table 4: Amino acid analysis of the total soft tissues of Spathopsis rubens arcuata collected from Al-Mahmoudia canal, Zawyet Ghazal during the first day of collection and third day of depuration.

\begin{tabular}{|c|c|c|c|}
\hline Variables & \multicolumn{3}{|c|}{$\%$ of Spathopsis rubens arcuata Infection } \\
\hline Prevalence & Conchophthirus & $\begin{array}{c}\text { Aspidogaster } \\
\text { conchicola }\end{array}$ & $\begin{array}{c}\text { Batracobdelloides } \\
\text { tricarinata }\end{array}$ \\
\hline Autumn & $0 \%$ & $4.44 \%$ & $26.66 \%$ \\
\hline Winter & $79.41 \%$ & $5.88 \%$ & $23.52 \%$ \\
\hline Spring & $61.76 \%$ & $20.58 \%$ & $11.76 \%$ \\
\hline Summer & $0 \%$ & $22.22 \%$ & $0 \%$ \\
\hline
\end{tabular}

Table 5: The seasonal prevalence of parasites in Spathopsis rubens arcuata. 
Citation: Elkhodary GM, Omran NE, Hassan AA, El-Saidy SA, Mona MH (2018) Nutritional Value of the Egyptian Freshwater Bivalve Spathopsis rubens arcuata Under the Effect of Depuration. J Aquac Res Development 9: 551. doi: 10.4172/2155-9546.1000551

when compared with total saturated fatty acids $(\mathrm{p}=0.001)$ as shown in Table 3.

\section{Determination of amino acid composition after depuration times}

The amino acid contents of the investigated $S$. rubens arcuata were determined before and after 3 days of depuration. 17 different amino acids in soft tissues of $S$. rubens arcuata including 9 essential amino acids and 8 nonessential amino acids were detected. Glutamine is the most abundant amino acid in S. rubens arcuata (45.247 to 61.196 $\mu \mathrm{g} / \mathrm{g}$ ) which constituted 14.98 to $16.50 \%$ of the total amino acids, followed by Aspartic acid (36.959 to $46.111 \mu \mathrm{g} / \mathrm{g})$, Alanine acid (21.875 to $27.105 \mu \mathrm{g} / \mathrm{g}$ ), and Leucine $(21.308$ to $26.624 \mu \mathrm{g} / \mathrm{g}$ ). Total amino acids (TAA) significantly increased after the third day of depuration $(p<0.01)$. before and after 3 days of depuration, the content of essential amino acids (EAA) was lower than nonessential amino acids (NEAA), and the ratio of TEAA: TNEAA was (0.68). Lysine: Arginine ratio was low on the first day of collection and third day of depuration (0.79 and 0.83 , respectively) as shown in Table 4.

\section{Investigation of $S$. rubens arcuata for parasitic infection}

A type of ciliates, Conchophthirus sp. (Figures 1A and 1B) was isolated from the hemolymph, mantle cavity, mantle, and gills of $S$. rubens arcuata. No trematode cercariae were shed from these clams. Gonads and intestine of $S$. rubens arcuata appeared free from any larval and adult stages of parasites. Adult Aspidogaster trematodes (Figure 2) were isolated from the mantle cavity, pericardial cavity, and gill filaments of $S$. rubens arcuata. The morphological study of this trematode using scanning electron microscope shows oral sucker and adhesive disc (Figures 3A-3E). During searching for parasites in S. rubens arcuata,
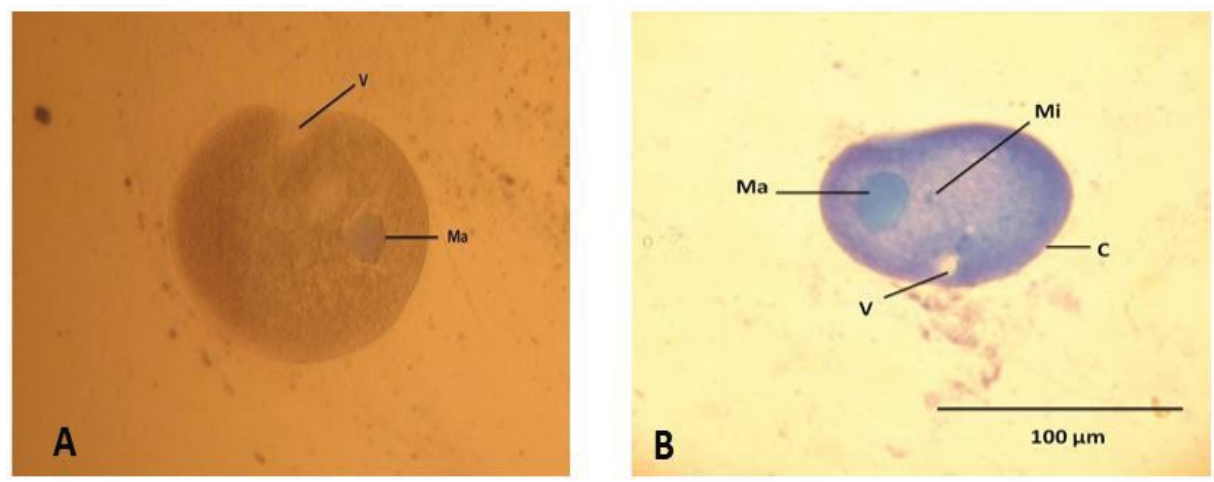

Figure 1: Light micrographs of Conchophthirus sp., 1A) Unstained whole mount; 1B) Stained whole mount showing cilia.

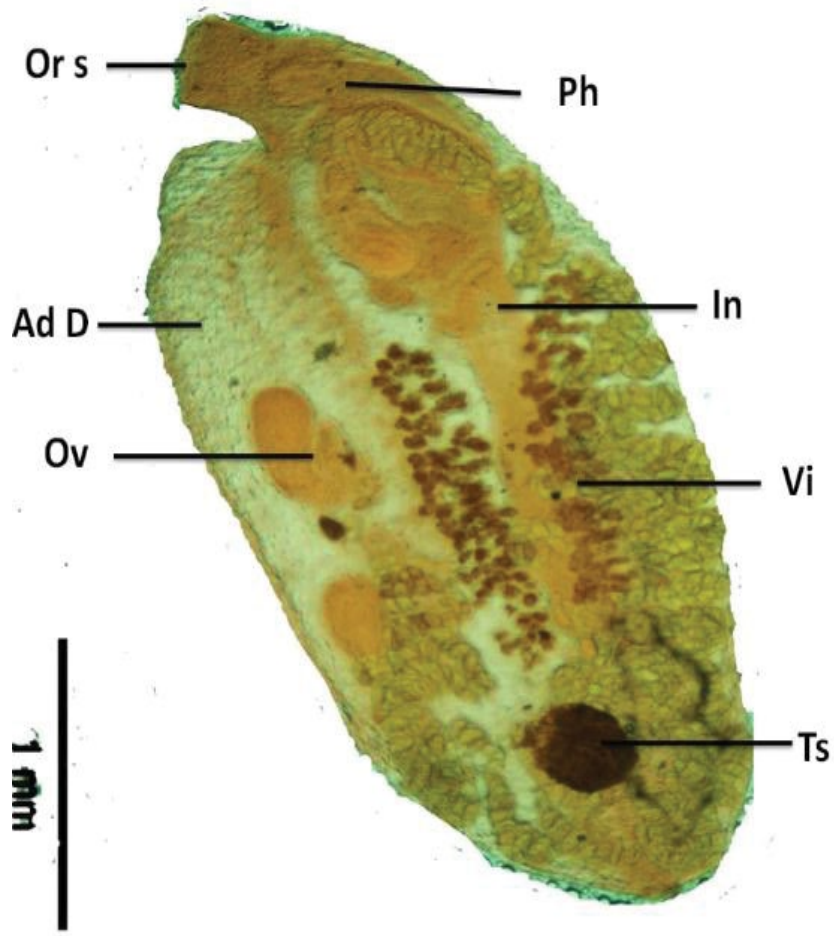

Figure 2: Light micrograph of Aspidogaster sp. Adhesive disc (Ad D), Intestine (In), Oral sucker (Or s), Ovary (Ov), Pharynx (Ph), Testis (Ts) and Vitellaria (Vi). 
Citation: Elkhodary GM, Omran NE, Hassan AA, El-Saidy SA, Mona MH (2018) Nutritional Value of the Egyptian Freshwater Bivalve Spathopsis rubens arcuata Under the Effect of Depuration. J Aquac Res Development 9: 551. doi: 10.4172/2155-9546.1000551
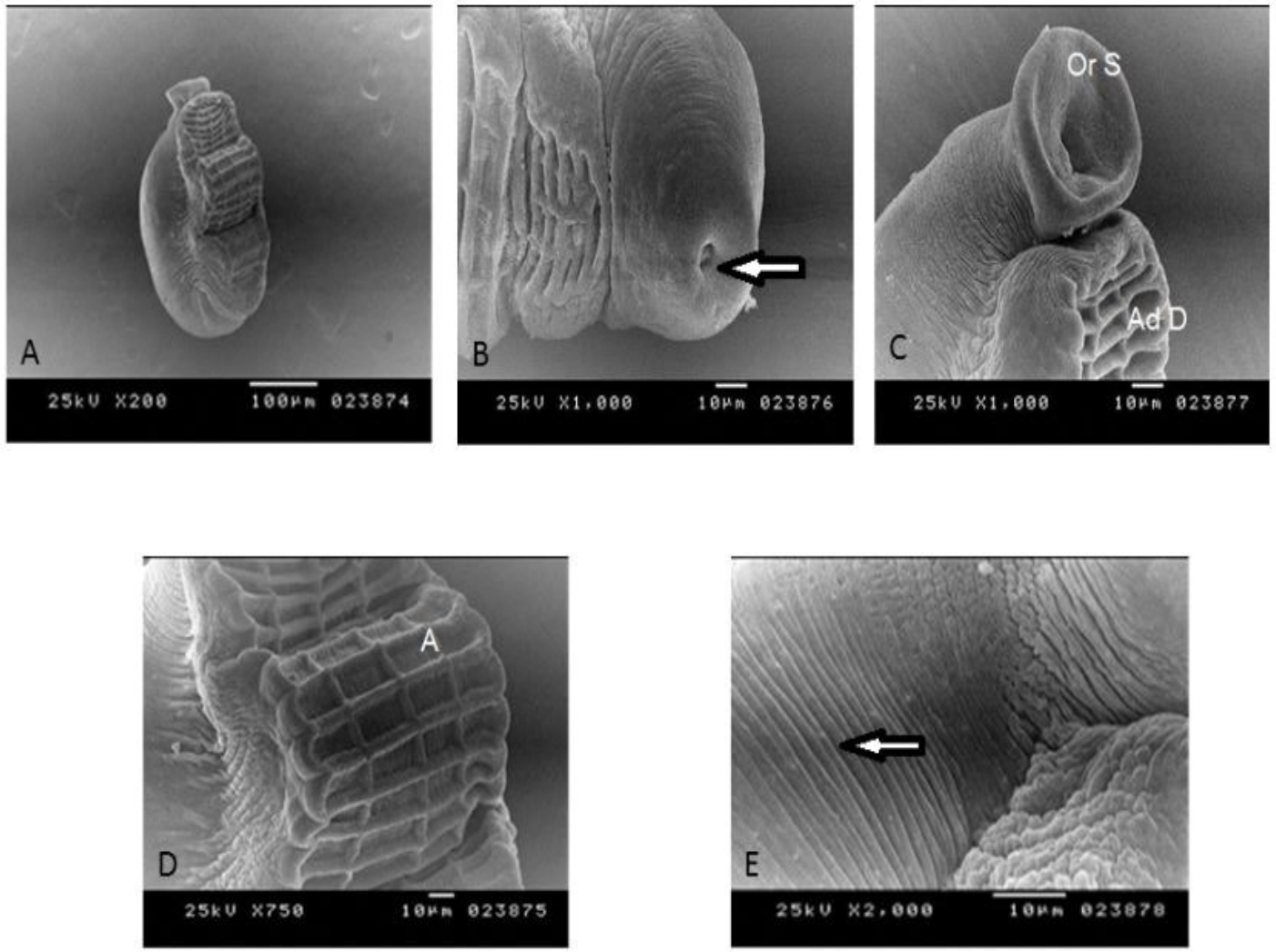

Figure 3: Scanning electron micrographs showing, 2A) Whole mount of Aspidogaster conchicola; 2B) Mouth opening (arrow); 2C) Oral sucker (Os); 2D) Ventral adhesive disc (Ad D) consisting of four longitudinal rows of alveoli (suckerlets) (A); 2E) Dorsal body surface elevated by transverse folds (arrow).
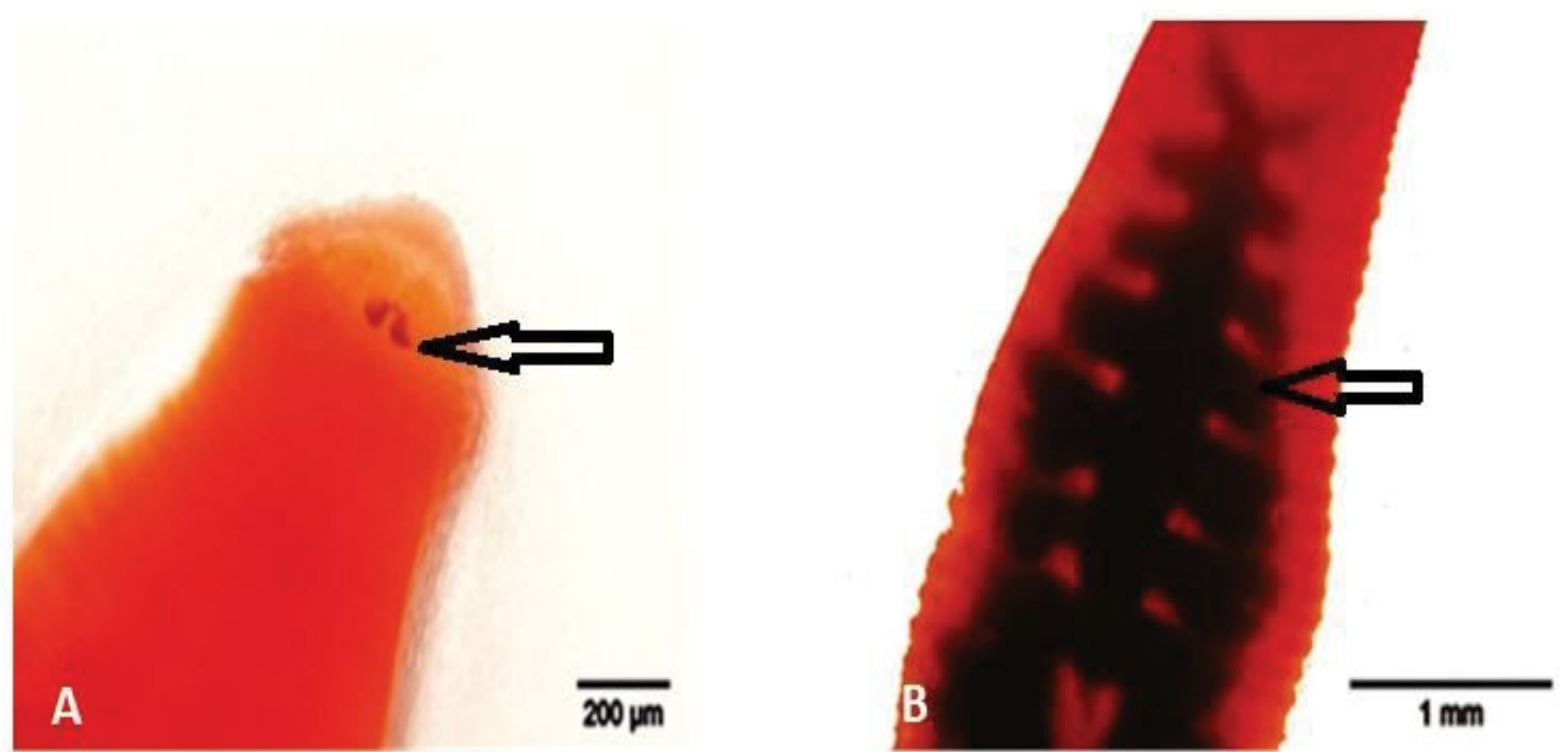

Figure 4: Light micrographs showing, 4A) The head of Batracobdelloides tricarinata having two pairs of eyes (arrow); 4B) Seven pairs of the lobed crop caecae (arrow). 

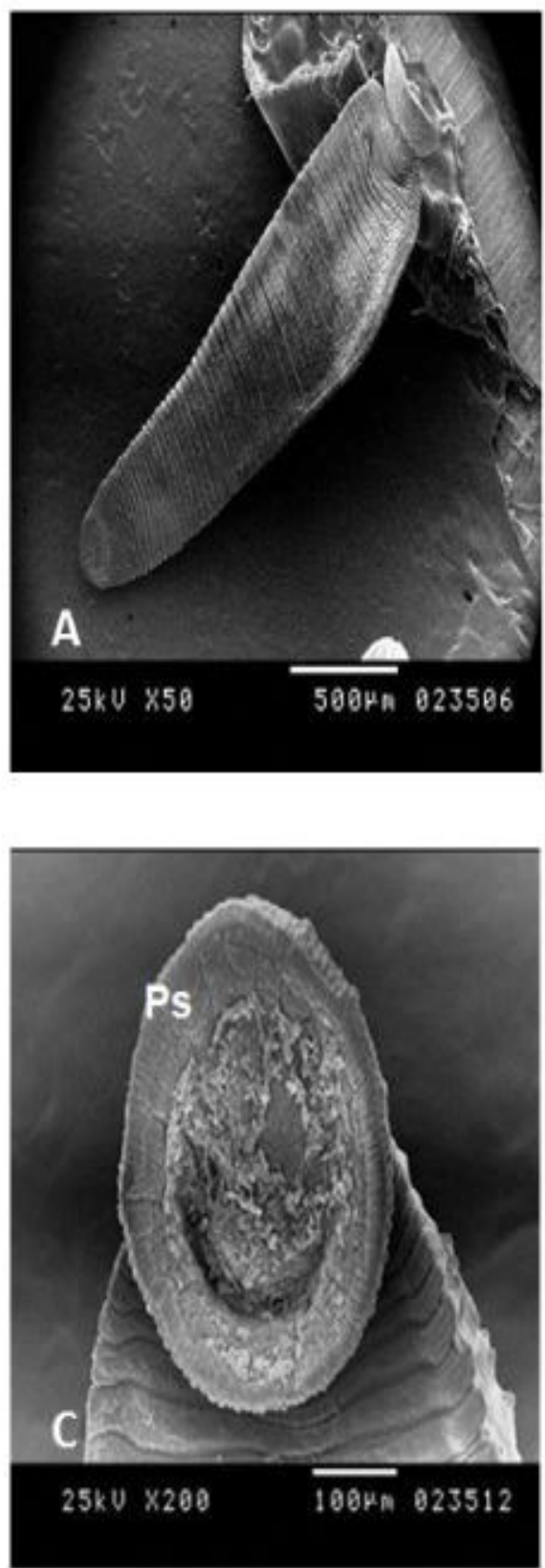
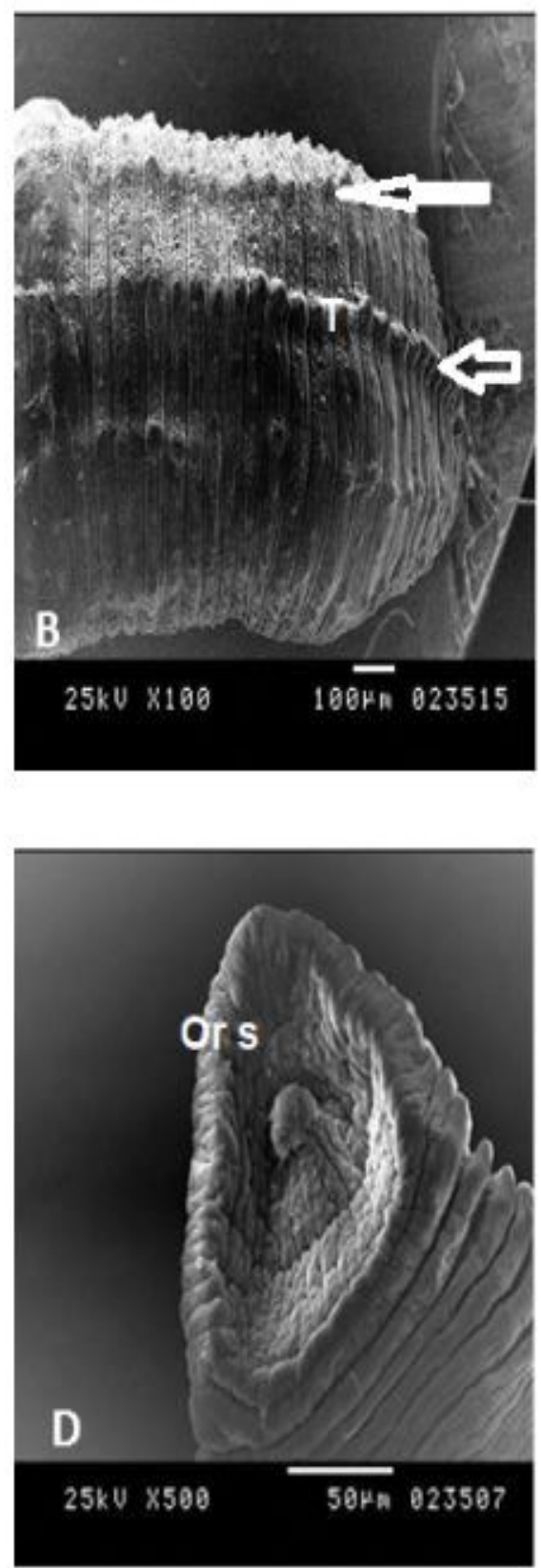

Figure 5: Scanning electron micrographs showing, 5A) Whole mount of Batracobdelloides tricarinata; $5 \mathrm{~B}$ ) Longitudinal rows of tubercles ( $\mathrm{T}$ ) which form ridges (arrows); 5C) Posterior sucker (Ps); 5D) Anterior sucker (Or s).

a few specimens of the African fish leech Batracobdelloides tricarinata that ranged from one to two specimens lay within the mantle cavity of S. rubens arcuata. This type of leech has two eye spots (Figure 4). The external structure studied by scanning electron microscope and shows that the tegument covered with longitudinal rows of tubercles (Figures 5A-5D).

The results showed that the prevalence of Conchophthirus in S. rubens arcuata during the winter season (79.41\%) was higher than spring season $(61.76 \%)$, while during autumn and summer seasons Conchophthirus was not detected in S. rubens arcuata (0\%). The prevalence of $\boldsymbol{A}$. conchicola infection in S. rubens arcuata was calculated, and it was higher in summer season $(22.22 \%)$ than in autumn, winter and spring seasons $(4.44 \%, 5.88 \%$, and $20.58 \%$, respectively). The results in Table 5 showed that the prevalence of $B$. tricarinata in the mantle cavity of S. Rubens Arcuata during autumn season $(26.66 \%)$ was higher than winter and spring seasons $(23.52 \%$ and $11.76 \%$, respectively), while during summer $B$. tricarinata was not detected in the mantle cavity of S. rubens arcuata $(0 \%)$.

\section{Discussion}

The real problem with eating freshwater clams is the fact that they are filter feeders, meaning that they constantly ingesting the water 
around them, and accumulating a variety of substances, including pollutants and toxins, in their own tissues. The current study was conducted to investigate the nutritional value, and assessment of the heavy metal levels in the $S$. rubens arcuata before and after depuration periods. In addition, to detect the presence of parasites in this clam. The present study showed that all metals measured in the collected tissues exceeded the permissible levels and this come in accordance with Fol and Abdel-Gaber [24]. But the heavy metal contents after a period of depuration in the soft tissues of these clams. it was appeared that heavy metal concentrations $(\mathrm{Cu}, \mathrm{Cd}$, and $\mathrm{Pb}$ ) in all tissues (foot, gills, mantle, and adductor muscles) of $S$. rubens arcuata showed a significant decrease on the $3^{\text {rd }}$ and $8^{\text {th }}$ days of depuration compared to their initial concentrations, but these reductions were more potent on the eighth day of depuration. This result was consistent with Cheung and Wong [25] who reported that the depuration for 7 days decreased $\mathrm{Cd}$ and $\mathrm{Pb}$ in three clam species Circe Sinensis, Gafrarium fumidum, and Tapes philippinarum. A similar result was reported by Geffard et al. [26] who found that $\mathrm{Cd}$ was eliminated more quickly than $\mathrm{Cu}$ and $\mathrm{Zn}$ when the kinetics of heavy metal elimination from Crassostrea gigas was recorded. Also, our findings were agreed with Yap et al. [27].

The obtained data showed that, the moisture percentages significantly increased after 8 days of depuration. This may be due to the increase of filtration rate. Liu et al. [28] found that the chronic toxic effects of heavy metals including $(\mathrm{Cu}, \mathrm{Pb}, \mathrm{Cd})$ on the filtration rate of immature blood clams, Tegillarca granosa were significantly inhibited. However. the protein, carbohydrates, ash, and lipids contents significantly reduced after 8 days of depuration. This may be agree with Anacleto et al. [29], who showed that the high mortality in Scrobicularia plana and reduced glycogen content may be due to the stressful conditions (e.g. lack of feed and sediment) during the depuration process, leading to a greater utilization of biochemical reserves.

Due to the depuration, the protein and carbohydrate contents increased on the $3^{\text {rd }}$ day and this could be due to the decreasing of electrolytes concentrations in $S$. rubens arcuata soft tissues after depuration period which in turn affect protein and carbohydrate synthesis. Previous data have reported that metal ions inactivate protein molecules through nonspecific binding or cross-linking of essential side chains and by promoting irreversible denaturation [30]. Moreover, depuration might lead to stress, which in turn affect proteins, carbohydrate, and lipids metabolism [31,32] Consistent with our findings, cadmium $(\mathrm{Cd})$ was found to interfere with many protein and carbohydrate metabolisms by inhibiting the enzymes involved in these processes [33]. The significant reduction of protein, carbohydrate, and lipid levels after $8^{\text {th }}$ days of depuration may be due to the absence of food during the depuration process and the consumption of these substances during the depuration periods.

In the present study, increasing of fatty acids number in the soft tissues of $S$. rubens arcuata after 3 days of depuration, especially the unsaturated fatty acids, which indicate that eating $S$. rubens arcuata after 3 days of depuration, could reduce the amount of cholesterol in the blood [34]. Moreover, previous studies showed that PUFA plays a vital role in alleviating cardiovascular disease, type- 2 diabetes, inflammatory ailments, and autoimmune disorders [35-37], and Connor [38] reported that omega 3 fatty acids prevent cardiovascular disease. Also, Nettleton [39] found that omega 3-fatty acids are a good nutritional aspect of fats since they have a much lower incidence of heart disease and lower total plasma cholesterol. The present study reported that after depuration for 3 days, a significant increase of the EPA, DHA, ARA, Palmitic and Oleic acids, these findings were consistent with previous studies reported by Fokina and Nemova [40].

The concentrations of total essential and nonessential amino acids were significantly increased in the total soft tissues of $S$. rubens arcuata after depuration periods, and this can be backed to the decreasing of heavy metals $(\mathrm{Cu}, \mathrm{Cd}$, and $\mathrm{Pb})$ concentrations in $S$. rubens arcuata tissue after depuration period. Whereas Cd toxicity can impact on biochemical constituents such as glycogen, total proteins, lipid, and free amino acids [41]. Also, $\mathrm{Cu}$ ions can inhibit the physiological activity, thereby decreasing the uptake of amino acids and consequently their distribution to other tissues [42].

Parasitic investigation of $S$. rubens arcuata during seasonal periods showed the presence of a type of ciliates Conchophthiridae sp. This parasite was found in the epithelial surfaces of the mantle, outer gill surfaces, in the gill water tubes, and supra-branchial cavities of the clam and this finding was consistent with the previous study by Grizzle and Brunner [43].

Our results indicated that the prevalence of Conchophthirus in the mantle cavity of $S$. rubens arcuata during the winter season was high, while in summer season was absent. The absence of Conchophthirus in the mantle cavity of $S$. rubens arcuata during summer and autumn seasons could hypothetically be explained by the difference in the chemical content of the mantle cavity mucus. Chuseve et al. [44] reported that the abundance of protozoans Conchophthirus acuminatus in zebra mussels Dreissena was positively associated with water temperature, whereas they were highest during summer and lower in winter.

Aspidogaster conchicola was found in the mantle cavity, pericardial cavity, and gill filaments of $S$. rubens arcuata. This consistent with Duobinis-Gray et al. [45] who found that A. conchicola specimens are typically found in the pericardial and renal cavities of bivalve molluscs. A high prevalence of A. conchicola in S. rubens arcuata was low and ranged from 4.44-22.22\%. Similar results have been reported previously by Yuryshynets and Krasutska [46]. High prevalence of $A$. conchicola was observed in the summer season. The reproduction rate of parasites may be greater at a higher temperature and lower water quality leading to increased parasites $[47,48]$. This finding was explained by Khurshid and Ahmad [49] who found that the period, which starts in the spring and continued to early summer. Also, Singh and Mishra [50] found that the higher abundance of helminth parasites during summer season was probably due to a higher temperature and lower immunity during this season which can facilitate increasing the susceptibility of disease and the transmission of parasites in their hosts.

\section{Conclusion}

In this study, a few specimens of the African fish leech Batracobdelloides tricarinata ranged from one to two specimens were found in the mantle cavity of $S$. $r$. arcuata as indicated by Appleton [51] who reported B. tricarinata in mollusc species such as Bulinus africanus, Lanistes ovum, Caelatura kunenensis, Mutela mabilli, and Aspatharia wahlbergi. According to Oosthuizen [52], Who observed no indication of parasitism by $B$. tricarinata in a variety of aquatic mollusc species. The present study indicates that the relationship between $B$. tricarinata and S. r. arcuata may be commensal, the leech utilizing the clam's shell for protection, and the leech partially protects the clam from infection by larval trematodes whereas in this study, none of the clams harboring $B$. tricarinata was infected by larval and adult trematodes. This observation agrees with Brooks and Welsch [53]. who found that 
Citation: Elkhodary GM, Omran NE, Hassan AA, El-Saidy SA, Mona MH (2018) Nutritional Value of the Egyptian Freshwater Bivalve Spathopsis rubens arcuata Under the Effect of Depuration. J Aquac Res Development 9: 551. doi: 10.4172/2155-9546.1000551

the same commensal relationship between Marvinmeyeria Lucida (Annelida: Hirudinea) and Helisoma trivolvis (Mollusca: Gastropoda) in Nebraska. This can explain the high prevalence of $A$. conchicola in summer season $(22.22 \%)$ when $B$. tricarinata was completely absent and low prevalence of $A$. conchicola (4.44\%) in the autumn season when there was a high prevalence of B. tricarinata $(26.66 \%)$. According to the given results it is suggested that $S$. rubens arcuata can be a good source of food with high protein and low-fat contents and free of parasitic diseases. But with a recommendation that marketing of this clam must be after a period of depuration ranged from 3 to 8 days.

\section{References}

1. Dong FM (2001) The nutritional value of shellfish in Washington Sea Grant Seattle, Washington, USA. p: 1-8.

2. Shetty S, Tharavathy NC, Lobo RO, Shafakatullah N (2013) Seasonal changes in the biochemical composition of freshwater bivalves, Parreysia spp. from Tungabhadra river, Karnataka. Int J Pharm Sci Res 4: 94-99.

3. Nesheim MC, Yaktine AL (2007) Seafood choices: Balancing benefits and risks. Food and Nutrition Board, Institute of medicine, National Academies Press, Washington, D.C., USA

4. Beukema JJ (1997) Caloric values of marine invertebrates with an emphasis on the soft parts of marine bivalves. Oceanogr Mar Biol 35: 387-414.

5. Galap C, Leboulenger F, Grillot JP (1997) Seasonal variations in biochemical constituents during the reproductive cycle of the female dog cockle Glycymeris glycymeris. Mar Bio 129: 625-634

6. Brockington S (2001) The seasonal energetics of the Antarctic bivalve Laternula elliptica (King and Broderip) at Rothera Point, Adelaide Island. Polar Biol 24: 523-530.

7. Croci L, Suffredini E, Cozzi L, Toti L (2002) Effects of depuration of molluscs experimentally contaminated with Escherichia coli, Vibrio cholerae 01 and Vibrio parahaemolyticus. J Appl Microbiol 92: 460-465.

8. Formiga-Cruz M, Allard AK, Conden-Hansson AC, Henshilwood K, Hernroth $\mathrm{BE}$, et al. (2003) Evaluation of potential indicators of viral contamination in shellfish and their applicability to diverse geographical areas. Appl. Environ. Microbiol 69: 1556-1563.

9. El-Shenawy NS (2004) Heavy-metal and microbial depuration of the clam Ruditapes decussatus and its effect on bivalve behavior and physiology. Environ Toxicol 19: 143-153.

10. Mason CF (2002) Biology of freshwater pollution. $4^{\text {th }}$ ed. Essex Univeristy, England: $387 p$

11. Egan H, Kirk SR, Sawyer R (1981) Pearson's chemical analysis of foods, $8^{\text {th }}$ edition book. Edinburgh, Churchill Livingstone, New York, USA.

12. AOAC (2000) Official methods of analysis of AOAC. International (17th edn), Gaithersburg, MD, USA, Association of Analytical Communities.

13. Murakami K, Yamaguchi Y, Sugawa-Katayama Y, Katayama M (1986) Effect of water depth on seasonal variation in the chemical composition of Akamoku, Sargassum horneri (Turner) C. Agardh. J Assoc Off Anal Chem 69: 370.

14. Dubois MKA, Gilles JK, Hamilton PAR, Smith F (1956) Colorimetric method for determination of sugars and related substances. Anal Chem 28: 350-356.

15. AOAC (1995) Method 900.02, 934.01, 954.02, 955.04, 960.05. Official Methods of Analysis of AOAC International, (16th edn), AOAC International, Virginia, Canada.

16. Block RJ, Durrum E, Zweig G (1958) A manual of paper chromatography and paper electrophoresis. Academic Press, New York, USA.

17. Radwan S (1978) Coupling of two-dimensional thin-layer chromatography with gas chromatography for the quantitative analysis of lipid classes and their constituent fatty acids. J Chromatogr Sci 16: 538-542.

18. Kigadye E, Nkwengulila G (2001) The occurrence of digenean larvae in freshwater snails at Mbezi-Temboni pond, Dar es Salaam. Tanz J Sci 27: 57-64.

19. Abd El-Rahman HA (1998) Studies on some protozoan blood parasites of some birds in Qena Governorate with special reference to malarial parasites. Faculty of Science, Sohag University, Egypt.
20. Brooks DR, Welsch NJ (1977) Marvinmeyeria lucida (Moore, 1954) (Annelida: Hirudinea) A Commensal of Helisoma trivolvis (Say) (Mollusca: Gastropoda) in Nebraska. Nebr Acad Sci 1: 21.

21. Hendrix SS, Overstreet RM (1977) Marine aspidogastrids (Trematoda) from fishes in the northern Gulf of Mexico. J Parasitol 63: 810-817.

22. Abd El-Rahman HA (2004) Studies on parasitic helminths of some species of fishes from Hurghada, Red Sea, Egypt taxonomy and some ecological phenomena. Faculty of Science, Sohag University.

23. Hassan HF, Saeed IS (2001) Light and electron microscope studies of the adult of Pleurogenoides medians (Olsson, 1876) (Trematoda: Lecithodendriidae) from Iraqi marsh frogs Rana ridibunda. Bull Iraq Nat: 9: 35-41.

24. Fol M, Abdel-Gaber R (2018) Biomarker Approach of Freshwater Mussels Nitia teretiuscula and Spathopsis rubens (Bivalvia: Unionidae, Mutelidae) as Invertebrate Bioindicators in Monitoring Aquatic Environmental Quality. Int $J$ Sci Res 7: 1618-1628.

25. Cheung Y, Wong M (1997) Depuration and bioaccumulation of heavy metals by clams from Tolo Harbour, Hong Kong. Toxicol Environ Chem 58: 103-116.

26. Geffard O, Budzinski H, His E, Seaman MN, Garrigues P (2002) Relationships between contaminant levels in marine sediments and their biological effects on embryos of oysters, Crassostrea gigas. Environ Toxicol Chem 21: 2310-2318.

27. Yap CK, Ismail A, Tan SG, Omar H (2003) Accumulation, depuration and distribution of cadmium and zinc in the green-lipped mussel Perna viridis (Linnaeus) under laboratory conditions. Hydrobiologia 498: 151-160.

28. Liu GX, Shu MA, Chai XL, Shao YQ, Wu HX, et al. (2014) Effect of chronic sublethal exposure of major heavy metals on filtration rate, sex ratio, and gonad development of a bivalve species. Bull Environ Contam Toxicol 92: 71-74.

29. Anacleto P, Maulvault AL, Nunes ML, Carvalho ML, Rosa R, et al. (2015) Effects of depuration on metal levels and health status of bivalve molluscs. Food Control 47: 493-501.

30. Ulmer DD (1970) Effects of metals on protein structure. In Effects of metals on cells, subcellular elements and macromolecules. In: Maniloff J, Coleman JR Miller MW (eds). Charles C. Thomas Publishers, Spring field, pp: 11-35.

31. Bhaskar M, Reddy GV, Murthy VK, Reddama P, Govindappa S (1982) Branchial protein metabolism of freshwater fish, Tilapia mossambica (Peters) during acute exposure and acclimation to sublethal alkaline water. Proceedings of Indian Academy of Sciences, Animal Sciences, 91: 235-241.

32. El-Khodary GM, El-Sherief S, Ghonium A (2011) Concentration of heavy metals and chemical composition of tissues in female mantis shrimp Oratosquilla Massavensis in the Eastern Harbour and Abu-Qir (Alexandria, Egypt). Egyp J Zool 57: 83-96.

33. Sobha K, Poornima A, Harini P, Veeraiah K (2007) A study on biochemical changes in the fresh water fish, Catla catla (Hamilton) exposed to the heavy metal toxicant cadmium chloride. Kathmandu Univ J Sci, Engin Techno 3: 1-11.

34. Sacks FM, Katan M (2002) Randomized clinical trials on the effects of dietary fat and carbohydrate on plasma lipoproteins and cardiovascular disease. Am J Med 113: 13-24.

35. Simopoulos AP (2002) Omega-3 fatty acids in inflammation and autoimmune diseases. J Am Coll Nutr 21: 495-505.

36. Hooper L, Thompson RL, Harrison RA, Summerbell CD, Moore H, et al (2004) Omega 3 fatty acids for prevention and treatment of cardiovascular disease. Cochrane Database Syst Rev 4: CD003177.

37. Bruckner G (1992) Fatty acids and cardiovascular diseases. In: Fatty acids in foods and their health implications Chow, C. K. (Ed), Marcel Dekker, New York, USA. pp: $375-752$

38. Connor WE (2000) Importance of $n-3$ fatty acids in health and disease. Am J Clin Nutr 71: 171S-175S

39. Nettleton JA (1995) Omega-3 fatty acids and health. Chapman and Hall, New York, USA. p. 359

40. Fokina NN, Nemova NN (2012) Fatty acid composition of blue mussels Mytilus edulis changes in response to cadmium and copper effects. Comparative Biochemistry and Physiology Part A: Mol Integr Physiol 163: S16.

41. Sobha K, Poornima A, Harini P, Veeraiah K (2007) A study on biochemical changes in the fresh water fish, Catla catla (Hamilton) exposed to the heavy metal toxicant cadmium chloride. Kathmandu Univ J Sci Engin Technol 3: 1-11. 
Citation: Elkhodary GM, Omran NE, Hassan AA, El-Saidy SA, Mona MH (2018) Nutritional Value of the Egyptian Freshwater Bivalve Spathopsis rubens arcuata Under the Effect of Depuration. J Aquac Res Development 9: 551. doi: 10.4172/2155-9546.1000551

42. Viarengo A, Pertica M, Mancinelli G, Capelli R, Orunesu M (1980a) Effects of copper on the uptake of amino acids, on protein synthesis and on ATP conten in different tissues of Mytilus galloprovincialis Lam. Mar Environ Res 4: 145-152.

43. Grizzle JM, Brunner CJ (2009) Infectious diseases of freshwater mussels and other freshwater bivalve mollusks. Rev Fish Sci 17: 425-467.

44. Chuseve R, Mastitsky SE, Zaiko A (2012) First report of endosymbionts in Dreissena polymorpha from the brackish Curonian Lagoon, SE Baltic Sea. Oceanologia 54: 701-713.

45. Duobinis-Gray LF, Urban EA, Sickel JB, Owen DA, Maddox WE (1991) Aspidogastrid (Trematoda) parasites of unionid (Bivalvia) molluscs in Kentucky Lake. J Helminthol Soc Washing 58: 167-170.

46. Yuryshynets V, Krasutska N (2009) Records of the parasitic worm Aspidogaster conchicola (Baer, 1827) in the Chinese pond mussel Sinanodonta woodiana (Lea, 1834) in Poland and Ukraine. Aquatic Invasions 4: 491-494.

47. Nie P (1996) Co-occurrence and microhabitat of Ancyrocephalus mogurndae (Monogenea) and Henneguya weishanensis (Myxosporea) on gills of the mandarian fish, Siniperca chuatsi. Folia Parasitologica 43: 272-276.

48. Ozer A, Ozturk T (2005) Dactylogyrus cornu Linstow, 1878 (Monogenea) infestations on Vimba (Vimba tenella, Nordmann, 1840) caught in the Sinop Region of Turkey in Relation to the Host Factors. Turk J Vet Anim Sci 29 1119-1123.

49. Khurshid I, Ahmad F (2013) Population dynamics of parasites as an evaluation metric to assess the trophic quality of fresh water bodies: A case study showing relationship of infection level of helminths in Schizothorax spp. of River Sindh Kashmir. Int j fish Aquat 2: 206-209.

50. Singh K, Mishra A (2013) A comparative study on seasonal distribution of the helminth parasites communities of some catfishes. Int J Pharma Bio Sci 4 19-30.

51. Appleton C (1979) The Unionacea (Mollusca, Lamellibranchiata) of southcentral Africa. Trustees of the South African Museum.

52. Oosthuizen JH (1989) Redescription of the African fish leech Batracobdelloides tricarinata (Blanchard, 1897) (Hirudinea: Glossiphoniidae). Hydrobiologia 184 153-164.

53. Brooks DR, Welsch NJ (1977) Marvinmeyeria lucida (Moore, 1954) (Annelida: Hirudinea) A Commensal of Helisoma trivolvis (Say) (Mollusca: Gastropoda) in Nebraska. Nebr Acad 1: 21. 